\title{
PENGEMBANGAN PERANGKAT PEMBELAJARAN MODEL PEMBELAJARAN KOOPERATIF TIPE TWO STAY TWO STRAY (TSTS) BERORIENTASI PENDIDIKAN KARAKTER BERBASIS KONSTRUKTIVISME MATERI LINGKARAN KELAS VIII
}

\section{THE LEARNING SET DEVELOPMENT OF COOPERATIVE LEARNING MODEL OF TWO STAY TWO STRAY (TSTS) TYPE CHARACTER EDUCATION ORIENTED BASED ON CONSTRUCTIVISM OF CIRCLES MATERIAL FOR $8^{\text {th }}$ GRADE}

\author{
Sofia Bardina \\ SMP Negeri 5 Pati \\ Email: sofiabardina@yahoo.co.id
}

Naskah Masuk: 4 Februari 2015 Naskah Revisi: 27 Maret 2015 Naskah Diterima: 29 April 2015

\begin{abstract}
This research aimed to develop the valid and effective learning set of mathematics through cooperative learning model of TSTS type character education oriented based on constructivism by $C D P$ of circles materials, and then it resulted an effective and valid learning set. The learning set would be developed were: syllabus, RPP, BPD, CDP, and THB. Data were obtained by observation and test. Data were analyzed descriptively using completeness test, $t$-test, and regression analysis. The mean scores for validation test were: Syllabus $=4.54 ; R P P=4.53 ; B P D=4.62 ; C D P=4.80$ and THB was valid. Field test showed that the learning sets were effective. It was proofed by the completeness of TBH with the average score was higher than 67 (exceeding 75\% of total student). Learning activities positively affected $80 \%$ of THB. The mean THB of experiment group was 73.36, while that of control class was 55.00. It proofed that experiment group showed higher skill than control group. Based on those results, it can be concluded that the learning set was valid and effective. It meant that the development of learning set succeeded and it was qualified to be used as mathematic learning method in Junior High School level.
\end{abstract}

Keywords: cooperative learning TSTS type, character education, constructivism, learning set development.

\begin{abstract}
ABSTRAK
Penelitian ini untuk mengembangkan perangkat pembelajaran matematika dengan Model Pembelajaran Kooperatif Tipe TSTS Berorientasi Pendidikan Karakter Berbasis Konstruktivisme Berbantuan CDP kelas VIII yang valid dan efektif. Tujuan dari penelitian ini adalah untuk menghasilkan perangkat pembelajaran yang valid dan efektif. Perangkat pembelajaran yang dikembangkan adalah Silabus, RPP, BPD, CDP dan THB. Cara pengambilan data dengan observasi dan tes. Data tes diolah dengan analisis deskriptif uji ketuntasan, uji banding $t$ dan uji regresi. Hasil validasi terhadap perangkat pembelajaran valid dengan rata-rata skor untuk Silabus $=4,54 ; R P P=4,53 ; B P D=4,62 ; C D P=4,80$ dan $T H B$ valid. Uji coba lapangan diperoleh hasil perangkat pembelajaran efektif. Keefektifan, diperoleh dari hasil uji ketuntasan THB dengan rataan nilai > 67 melebihi 75\% dari peserta didik, ada pengaruh positif aktivitas terhadap THB sebesar $80 \%$. Rataan THB pada kelas eksperimen sebesar 73,36 sedangkan rataan THB di kelas kontrol sebesar 55,00 sehingga rataan kemampuan kelas eksperimen lebih besar dari kelas kontrol. Dari analisis hasil tersebut di atas dapat disimpulkan bahwa perangkat adalah valid dan efektif. Hal ini berarti bahwa pengembangan perangkat tercapai dan layak digunakan dalam pembelajaran matematika di SMP.
\end{abstract}

Kata kunci: model pembelajaran kooperatif tipe TSTS, pendidikan karakter, konstruktivisme, pengembangan perangkat pembelajaran. 


\section{PENDAHULUAN}

Matematika merupakan sarana berpikir untuk menumbuhkembangkan pola pikir logis, sistematis, obyektif, kritis, dan rasional yang harus dibina sejak pendidikan dasar. Oleh sebab itu matematika harus mampu menjadi salah satu sarana untuk meningkatkan daya nalar peserta didik dan dapat meningkatkan kemampuan dalam mengaplikasikan matematika untuk menghadapi tantangan hidup sesuai yang termuat dalam Kurikulum Tingkat Satuan Pendidikan (KTSP). Ironisnya matematika adalah pelajaran yang kurang diminati oleh peserta didik sehingga mengakibatkan rendahnya kinerja peserta didik dalam matematika. Dan geometri merupakan salah satu materi dalam matematika yang tidak mudah untuk dipelajari karena memiliki tingkat keabstrakan tinggi, karena objek yang dibicarakan di dalamnya merupakan benda-benda pikiran yang sifatnya abstrak.

Aydin dkk (2007) menyatakan selama beberapa dekade, banyak peserta didik yang mengalami kesulitan dalam pembelajaran geometri baik pada sekolah menengah maupun perguruan tinggi dengan menunjukkan kinerja yang buruk dengan berbagai kendala. Hal ini disebabkan beberapa faktor antara lain dari faktor pendidik yang kurang tepat dalam pemilihan model, strategi dan media pembelajaran yang digunakan, sehingga tidak mendapatkan hasil pembelajaran yang efektif. Selain bertujuan memberikan pemahaman tentang materi pembelajaran secara baik, penyelenggaraan pendidikan perlu menumbuhkembangkan watak/karakter peserta didik sehingga memiliki keaktifan belajar yang baik dan mampu bersaing, beretika, bermoral, sopan santun serta berinteraksi dengan masyarakat. Menurut Khan (2010), pendidikan karakter merupakan shock therapy tidak saja mendongkrak nilai akhir peserta didik tetapi juga kualitas pendidikan.

Disebutkan dalam KTSP, dalam mengelola pembelajaran pendekatan dan strategi yang dipilih hendaknya bersandar pada pandangan konstruktivisme yang memberi kesempatan luas kepada peserta didik untuk secara aktif membangun pengetahuannya sendiri. Pembelajaran yang berbasis pada teori konstruktivisme telah melahirkan model pembelajaran kooperatif atau cooperative learning (Pujiati, 2008). Strategi pembelajaran kooperatif memberikan dampak positif pada peserta didik yang tercermin pada peningkatan prestasi akademik, sikap sosial dan perilaku (Miller dan Peterson, 2010). Salah satu model pembelajaran kooperatif adalah tipe TSTS (Two Stay Two Stray) atau "dua tinggal-dua tamu".

Berdasarkan uraian di atas rumusan masalah dalam penelitian ini adalah bagaimanakah mengembangkan perangkat pembelajaran model TSTS berorientasi pendidikan karakter berbasis konstruktivisme materi lingkaran kelas VIII yang valid dan efektif. Adapun tujuan dari penelitian ini adalah untuk mengembangkan perangkat pembelajaran dengan model TSTS berorientasi pendidikan karakter berbasis konstruktivisme materi lingkaran kelas VIII.

\section{TINJAUAN PUSTAKA}

\section{Model Pembelajaran TSTS}

Teknik pembelajaran kooperatif TSTS dikembangkan oleh Spencer Kagan (Lie, 2010). Struktur ini memberikan kesempatan kepada kelompok untuk membagikan hasil dan informasi dengan kelompok lain. Langkah-langkah dalam pembelajaran kooperatif: 1) Peserta didik dibagi dalam kelompok berempat; 2) Pendidik memberi tugas dan masing- 
masing kelompok mengerjakannya; 3) Kelompok memutuskan jawaban yang paling benar dan memastikan setiap anggota kelompok memahami jawaban tersebut; 4) Setelah selesai, dua orang dari masing-masing kelompok akan meninggalkan kelompoknya dan bertamu ke dua kelompok yang lain. Dua orang yang tinggal dalam kelompok bertugas membagikan hasil kerja dan informasi mereka ke tamu mereka. Pembagian tugas ini yang mengatur adalah pendidik dan sudah dirancang sebelumnya; 5) Tamu mohon diri dan kembali ke kelompok mereka sendiri dan melaporkan temuan mereka dari kelompok lain; dan 6) Kelompok mencocokkan dan membahas hasil-hasil kerja mereka.

\section{Pendidikan Karakter}

Pendidikan karakter berbasis potensi diri merupakan pendidikan yang tidak saja membimbing dan membina setiap peserta didik untuk memiliki kompetensi intelektual (kognitif) dan kompetensi ketrampilan mekanik (pshycomotoric) tetapi juga berfokus pada pencapaian pembangunan karakter (affective) (Khan, 2010). Pendidikan karakter berbasis potensi diri antara lain adalah mengembangkan nilai karakter dalam hubungannya dengan diri sendiri yang meliputi: jujur, bertanggung jawab, disiplin, kerja keras, berpikir logis, kritis, kreatif, dan inovatif (Depdiknas, 2010).

\section{Pembelajaran Konstruktivime}

Teori konstruktivisme yang terpenting adalah bahwa pendidik tidak hanya sekedar memberikan pengetahuan kepada peserta didik. Peserta didik harus membangun sendiri pengetahuannya. Peserta didik harus menemukan sendiri dan mentransformasikan informasi kompleks, mengecek informasi baru dengan aturan-aturan lama dan merevisinya apabila aturan-aturan itu tidak lagi sesuai (Trianto, 2007). Tahapan konstruktivisme dalam penelitian ini adalah: Apersepsi, Eksplorasi, Diskusi dan Penjelasan Konsep, Pengembangan Dan Aplikasi.

\section{Perangkat Pembelajaran}

Perangkat pembelajaran adalah sekumpulan sumber belajar yang memungkinkan pendidik dan peserta didik untuk melakukan kegiatan pembelajaran. Menurut Ibrahim dalam Usman (2001) menyatakan bahwa perangkat pembelajaran merupakan prasyarat bagi terjadinya interaksi belajar mengajar yang optimal. Perangkat pembelajaran yang dikembangkan dalam penelitian ini meliputi silabus, Rencana Pelaksanaan Pembelajaran (RPP), Buku Pesereta Didik (BPD), Compact Disc Pembelajaran(CDP) dan Tes Hasil Belajar (THB).

\section{Model Pengembangan Perangkat Pembelajaran}

Pengembangan perangkat pembelajaran dalam penelitian ini menggunakan model 4-D yang terdiri dari empat tahap yaitu: 1) Pendefinisian (define); 2) Perancangan (design); 3) Pengembangan (develop); dan 4) Penyebaran (deseminate) (Thiagarajan, 1974).

\section{Aktivitas Peserta Didik}

Aktivitas peserta didik selama proses pembelajaran berlangsung, sangat berpengaruh terhadap hasil belajar peserta didik. Aktivitas interaksi antara peserta didik dengan peserta didik, peserta didik dengan pendidik sangat diharapkan dalam kegiatan pembelajaran dengan metode TSTS berorientasi pendidikan karakter berbasis konstruktivisme dalam kelompok kecil. Karena dengan interaksi seperti ini memungkinkan peserta didik untuk dapat mengkonstruksi pengetahuannya, apakah berupa cara-cara, sifat-sifat atau suatu algoritma. Dalam kegiatan pembelajaran peserta didik tidak sekedar mendengarkan atau menerima konsep, prinsip dari 
pendidik, tetapi harus bisa menemukan konsep melalui bantuan pendidik atau teman sebayanya. Slavin dalam Hambali (2006) mengemukakan bahwa agar peserta didik dapat menemukan konsepkonsep sendiri dalam setiap kegiatan pembelajaran, peserta didik harus dilibatkan secara aktif dalam memecahkan masalah pada setiap kegiatan pembelajaran.

\section{METODE PENELITIAN}

Penelitian ini adalah jenis penelitian pengembangan. Adapun pengembangan yang dimaksud adalah pengembangan perangkat pembelajaran materi lingkaran yang meliputi: silabus, RPP, BPD, CDP dan THB.

Model pengembangan yang digunakan untuk mengembangkan perangkat pembelajaran dalam penelitian ini adalah modifikasi dari model Thiagarajan, Semmel dan Semmel. Modifikasi yang dilakukan adalah penyederhanaan model dari empat tahap yaitu pendefinisian (define), perancangan (design), pengembangan (develop) dan penyebaran (desseminate) menjadi tiga tahap yaitu pendefinisian (define), perancangan (design) dan pengembangan (develop).
Subjek uji coba penelitian ini adalah peserta didik Kelas VIII SMP Negeri 2 Tlogowungu Pati yang terdiri dari 3 kelas paralel pada tahun pelajaran 2010/2011. Satu kelas dengan jumlah siswa 25 orang dijadikan subjek penelitian pada saat uji coba perangkat pembelajaran dan 2 kelas yang lain dengan jumlah siswa 25 orang dan 22 orang sebagai kelas eksperimen dan kelas kontrol.

Instrumen yang digunakan untuk mengumpulkan data dalam penelitian ini adalah: 1) Lembar validasi perangkat; 2) Lembar pengamatan aktifitas; dan 3) Tes hasil belajar.

\section{HASIL DAN PEMBAHASAN}

Kevalidan data diperoleh dengan meminta pertimbangan ahli. Hal ini sesuai dengan pernyataan Khabibah dalam Trianto (2007) bahwa aspek validitas dibutuhkan ahli dan praktisi untuk memvalidasi perangkat yang dikembangkan. Dalam penelitian ini perangkat pembelajaran yang telah divalidasi dikatakan valid, jika perangkat pembelajaran telah memenuhi validitas isi yang telah ditetapkan oleh validator dengan penilaian baik. Hasil perhitungan validasi dapat dilihat pada Tabel 1 .

Tabel 1.

Rekapitulasi Hasil Validasi Ahli

\begin{tabular}{|c|c|c|c|c|c|c|}
\hline \multirow{2}{*}{ No } & \multirow{2}{*}{ Validator } & \multicolumn{5}{|c|}{ Rata- rata Hasil Validasi } \\
\hline & & Silabus & RPP & BPD & CDP & THB \\
\hline 1 & 1 & 4.05 & 3.89 & 3.85 & 4 & $\mathrm{~V} / \mathrm{TR}$ \\
\hline 2 & 2 & 4.65 & 4.33 & 4.75 & 5 & $\mathrm{~V} / \mathrm{TR}$ \\
\hline 3 & 3 & 4.35 & 4.56 & 4.85 & 5 & $\mathrm{~V} / \mathrm{RK}$ \\
\hline 4 & 4 & 4.85 & 5 & 4.85 & 5 & $\mathrm{~V} / \mathrm{TR}$ \\
\hline 5 & 5 & 4.8 & 4.89 & 4.8 & 5 & $\mathrm{~V} / \mathrm{TR}$ \\
\hline \multicolumn{2}{|c|}{ Jumlah } & 22.7 & 22.67 & 23.1 & 24 & \\
\hline \multicolumn{2}{|c|}{ Rata-rata } & 4.54 & 4.53 & 4.62 & 4.8 & V / TR \\
\hline \multicolumn{2}{|c|}{ Kriteria } & Baik sekali & Baik sekali & Baik sekali & Baik sekali & Valid, revisi kecil \\
\hline \multicolumn{2}{|c|}{ Keterangan: } & \multicolumn{2}{|c|}{$\mathrm{TR}=$ tidak revisi } & & \multicolumn{2}{|c|}{$\mathrm{RK}=$ revisi kecil } \\
\hline
\end{tabular}

Sumber: Hasil Validasi (2011) 
Hasil validasi dari ke-5 validator menunjukkan bahwa perangkat pembelajaran matematika dengan model TSTS berorientasi pendidikan karakter berbasis konstruktivisme berbantuan CDP yang dikembangkan memenuhi kriteria valid sedikit revisi. Dengan hasil tersebut maka perangkat pembelajaran tersebut dapat digunakan dan siap diujicobakan untuk mengetahui tentang keefektifannya.

Model pengembangan perangkat pembelajaran yang digunakan dalam penelitian ini adalah 4-D yang dimodifikasi. Melalui serangkaian tahap pengembangan yakni tahap pendefinisian, perancangan, dan pengembangan maka diperoleh perangkat pembelajaran dengan model TSTS berorientasi pendidikan karakter berbasis konstruktivisme. Produk perangkat pembelajaran meliputi Silabus, RPP, BPD, CDP dan THB.
Penggunaan

perangkat pembelajaran dengan model TSTS berorientasi pendidikan karakter berbasis konstruktivisme di kelas eksperimen, menunjukkan bahwa peserta didik mencapai tuntas, dengan rata-rata 73,36 dan mencapai ketuntasan klasikal, yakni lebih dari $75 \%$ peserta didik mendapatkan nilai minimal 67. Sebanyak 25 peserta didik di kelas eksperimen, 19 peserta didik tuntas belajar (76\%) dan 6 peserta didik tidak tuntas belajar.

Hasil belajar peserta didik di kelas eksperimen lebih baik dibanding dengan hasil belajar peserta didik di kelas kontrol. Perbandingan tersebut dapat dilihat pada rata-rata yang diperoleh pada kelas eksperimen mempunyai rata-rata sebesar 73,36 sedangkan pada kelas kontrol ratarata 55,00 seperti yang ditunjukkan pada Tabel 2.

Tabel 2.

Uji Banding

Group Statistics

\begin{tabular}{|c|c|c|c|c|c|}
\hline & kelas & $\mathrm{N}$ & Mean & Std. Deviation & $\begin{array}{c}\text { Std. Error } \\
\text { Mean }\end{array}$ \\
\hline \multirow[t]{2}{*}{ kelasAB } & 1 & 25 & 73.36 & 15.234 & 3.047 \\
\hline & 2 & 22 & 5.00 & 11.288 & 2.407 \\
\hline
\end{tabular}

Sumber: Hasil Uji T (T Test) (2011)

Persamaan regresi yang didapatkan dari hasil penelitian adalah $\mathrm{Y}=-58,616+$ 1,945 X. Koefisien regresi sebesar 1,945 menyatakan bahwa setiap kenaikan $1 \%$, maka keaktifan siswa akan naik sebesar
1,945\%. Dengan keaktifan peserta didik memberi konstribusi terhadap Y sebesar $80 \%$ sedangkan sisanya $20 \%$ dipengaruhi faktor lain, seperti yang ditunjukkan pada Tabel 3.

Tabel 3.

Nilai R Square Aktivitas Peserta Didik

Model Summary

\begin{tabular}{|l|r|r|r|r|}
\hline Model & R & R Square & $\begin{array}{c}\text { Adjusted } \\
\text { R Square }\end{array}$ & $\begin{array}{r}\text { Std. Error of } \\
\text { the Estimate }\end{array}$ \\
\hline 1 & $.894^{\mathrm{a}}$ & .800 & .791 & 6.959 \\
\hline
\end{tabular}

a. Predictors: (Constant), keaktitan 
Coefficients $^{\mathrm{a}}$

\begin{tabular}{|c|c|c|c|c|c|c|}
\hline \multirow{2}{*}{\multicolumn{2}{|c|}{ Model }} & \multicolumn{2}{|c|}{$\begin{array}{c}\text { Unstandardized } \\
\text { Coefficients }\end{array}$} & \multirow{2}{*}{$\begin{array}{c}\begin{array}{c}\text { Standardized } \\
\text { Coefficients }\end{array} \\
\text { Beta }\end{array}$} & \multirow[b]{2}{*}{$t$} & \multirow[b]{2}{*}{ Sig. } \\
\hline & & $\mathrm{B}$ & Std. Error & & & \\
\hline & (Constant) & $\widehat{58.616}$ & 13.830 & & -4.238 & .000 \\
\hline & keaktifan & 1.945 & .203 & .894 & 9.592 & .000 \\
\hline
\end{tabular}

a. Dependent Variable: kelasA

Sumber: Hasil Uji Regresi (2011)

Menurut Suparlan dkk (2008), aktivitas peserta didik sebagai salah satu dasar untuk menentukan tingkat keberhasilan dalam belajar. Hal ini sejalan dengan penelitian Wijayanti (2007), Nugraheni (2009) dan Astuti (2010) yang menyatakan bahwa aktivitas peserta didik sangat berpengaruh terhadap tes hasil belajar.

Dengan demikian, berdasarkan pengembangan perangkat pembelajaran menggunakan model 4-D yang telah dimodifikasi, dihasilkan perangkat pembelajaran dengan model TSTS berorientasi pendidikan karakter berbasis konstruktivisme yang valid dan efektif untuk materi lingkaran.

\section{KESIMPULAN DAN SARAN}

\section{Kesimpulan}

Proses pengembangan perangkat pembelajaran model TSTS berorientasi pendidikan karakter berbasis konstruktivisme melalui modifikasi Thiagarajan, Semmel dan Semmel, menghasilkan produk perangkat pembelajaran matematika yang valid menurut para ahli, artinya hasil validasi perangkat pembelajaran oleh 5 validator menunjukan hasil sangat baik. Perangkat pembelajaran model TSTS berorientasi pendidikan karakter berbasis konstruktivisme juga dikatakan efektif karena 3 indikator efektif terpenuhi yaitu: 1) Tuntas pada THB; 2) Ada pengaruh aktivitas terhadap THB; 3) Hasil THB dalam pembelajaran menggunakan perangkat dengan model TSTS berorientasi pendidikan karakter berbasis konstruktivisme materi lingkaran lebih baik dibandingkan hasil THB dengan metode konvensional.

\section{Saran}

1. Perangkat pembelajaran matematika dengan model TSTS berorientasi pendidikan karakter berbasis konstruktivisme berbantuan CDP materi lingkaran kelas VIII telah terbukti valid dan efektif sehingga dapat digunakan sebagai alternatif dalam mengajar matematika.

2. Pendidik hendaknya meningkatkan keaktifan peserta didik dalam pembelajaran matematika, sehingga dapat menumbuhkan karakter dan hasil belajar peserta didik dapat lebih maksimal.

\section{DAFTAR PUSTAKA}

Astuti, I. P. 2010. Pengembangan Perangkat Pembelajaran Matematika Dengan Pendekatan Paikem Berbantuan CD Pembelajaran Materi Segitiga Kelas VII, Tesis. Semarang: Universita Negeri Semarang.

Aydin, E., E. Hallat., H. Jakubowski. 2007. Reform-based Curriculum and Motivation in Geometry. Eurasia Journal of Mathematics, Science \&Technology Education, 4(3): 285-292. 
Hambali. 2006. Pengembangan Perangkat Pembelajaran Pada Pokok Bahasan Persamaan Linier Dua Variabel Dengan Pendekatan Realistik Di Kelas Dua SMP Negeri 33 Makasar. Tesis. Surabaya: Universitas Negeri Surabaya.

Departemen Pendidikan Nasional. 2008. Himpunan Peraturan PerundangUndangan Republik Indonesia Bidang Pendidikan dan Kebudayaan. Jakarta: Sekjen Depdikbud.

Khan, Y. 2010, Pendidikan Karakter Berbasis Potensi Diri Mendongkrak Kualitas Pendidikan. Yogyakarta: Pelangi Publishing.

Lie, A. 2010. Cooperative Learning (Mempraktekkan Cooperative Learning di ruang-ruang kelas). Jakarta: Grasindo.

Miller, C. K., R. L. Peterson. 2010. Creating A Positive Climate Cooperative (www.indiana.edu/ safeschl, diakses 23 Juli 2010).

Nugraheni, N. 2009. Pengembangan Perangkat Pembelajaran Matematika dengan Pendekatan Kontekstual Berbasis Membaca untuk Meningkatkan Kreativitas Siswa. Tesis. Semarang: Universitas Negeri Semarang.

Pujiati, I. 2008. Peningkatan Motivasi dan Ketuntasan Belajar Matematika Melalui Pembelajaran Kooperatif Tipe STAD. Jurnal Ilmiah Kependidikan 1(1).
Suparlan., B. Dasim., M. Danny. 2008. Pakem (Pembelajaran Aktif Kreatif Efektif Menyenangkan). Bandung: Genesindo.

Thiagarajan., Semmel and Semmel. 1974. Instructional Development for Training Teachers of Exceptional Children. A sourcebook. Bloomington Indiana: Central for Innovation onthe Handicapped.

Trianto. 2007. Pengembangan Perangkat dalam Teori dan Praktek. Surabaya: Prestasi Pustaka.

Usman, U. 2001. Upaya Optimalisasi Kegiatan Belajar Mengajar. Jakarta: PT. Rosda Karya.

Wijayanti, D. A. 2007. Implementasi Model Pembelajaran STAD dan TSTS berbantuan CD Pembelajaran dan LKS Pokok Bahasan Segiempat Siswakelas VII semester 2. Tesis. Semarang: Universitas Negeri Semarang.

\section{BIODATA PENULIS}

Sofia Bardina, lahir di Kota Jepara pada tanggal 29 Oktober 1967. Pendidikan Magister Pendidikan Matematika UNNES. Saat ini bekerja sebagai Kepala SMP Negeri 5 Pati. 